\title{
Editorial:
}

\section{Curriculum re-design in a knowledge-based economy}

\author{
Rediseño curricular en la economía basada en el conocimiento
}

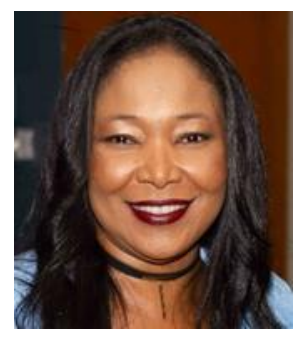

\author{
Racquel Warner (iD \\ Assistant Professor of Education Policy \\ Mohammed bin Rashid School of Government \\ EdD - University of Exeter (England) \\ Executive member of AIB MENA: Academy of International Business (AIB) \\ Middle East \& North Africa (MENA) \\ E-mail: racquel.warner@mbrsg.ac.ae \\ https://doi.org/10.22430/24223182.1252
}

Globalization and modernization present an ongoing challenge to many societies. As borders between nations become more porous due to the progress of technology, migration, and a more mobile labor force, each nation must devise a strategic response to promote human capital development in order to remain economically competitive in the global marketplace. One approach many countries have explored is the development of knowledge economies. Especially in OECD member states, knowledge is increasingly being identified as the key enabler of productivity and economic growth. This has led to a new paradigmatic understanding of the role of information, technology, and learning in economic performance. According to an OECD report, "the term knowledge-based economy stems from this fuller recognition of the place of knowledge and technology in modern OECD economies" (OECD, 1996, p.3). Consequently, contemporary societies are heavily focused on the education sector as a driver to meet national goals and attain global competitiveness in knowledge economies.

The full spectrum of the education sector has been undergoing significant reforms in order to fulfill its new mandate. Globally, there have been calls to overhaul the industrial-style pedagogical process to one that is best suited for the digital age. As these reforms are taking place, this is a great opportunity to align policies related to curriculum design with the statutory and regulatory constructs that are required in each educational context so that appropriate skills, knowledge, values, instruction, resource allocation, and physical infrastructure can all be focused on the development of 
competitive human capital. In the past, many developing countries adopted education models from their developed counterparts and super-imposed them in a context where they did not belong. In many cases, it was like trying to fit a round peg into a square hole; these instructional designs and contents had to undergo significant adaptation to address the local context. This new wind of reform brings with it the opportunity to democratize the education system in a manner that each country can develop its best model of instruction in order to meet the needs of learners and other stakeholders. This new environment requires adaptive learning models, personalized learning content, and the use of technology to access remote locations where a large portion of the population in developing countries remains unreached by the reforms that are taking place in urban areas.

Another factor that should be considered in curriculum and education policy reform is the demography of millennials and lifelong learners currently accessing education at the tertiary level. Extant research on the impact of millennials on higher education suggests that an innovative and technology-enabled environment is the best fit for this generation. Millennials are keen to be educated in a context where they can exercise their agency and be an active part of the learning process. The days of passive learning are past and higher education institutions, regardless of whether they are teaching business or biology, need to respond to the needs of this generation. According to the $\mathrm{OECD}$, institutions can achieve this goa by opening up to partnerships with the private sector, thus facilitating the growth of social and professional capital. (OECD, 2006). This change, could possibly lead to a more entrepreneurial graduating class who would be job creators rather than job seekers.

The practice of teaching about centralized, hierarchical theories of management and leadership is coming to an end. Instructional modalities that promote collaboration, 21st-century management thinking, innovation, and creativity should inform curriculum design. Present and future business environments, which are volatile and ambiguous, should adopt a new approach. Furthermore, students across all departments in universities and tertiary institutions require an authentic learning environment. Learners should be given opportunities to take responsibility for, lead, and derive instruction from mistakes. Exposure to real-time data, company performance reports, economic environments, and strategic planning can help students to develop the agile decision making and innovative thinking skills demanded by the industry. Technical knowledge about budgeting, staffing, quality control, and planning is still necessary, but instruction should go beyond to provide students with the higher-order skills that will make them more competitive in a knowledge economy.

For higher education institutions to meet the national and global need for high-capacity graduates who can make their countries competitive in the global knowledge economy, a full $360^{\circ}$ review of the current curriculum and the policies that rule educational practices is required. This will enable institutions to address blind spots that have existed for decades but are now hindering progress. Ultimately, successful organizations will be those able to: (1) shake off their strong dependence on theoretical and historical ideas of management and (2) democratize the andragogical process by embracing technology-enabled, multimodal, authentic, and relevant approaches. 


\section{REFERENCES}

OECD (1996). Competencies for the Knowledge Economy, OCDE/GD (96) 102, Available at http://www.oecd.org/innovation/research/1842070.pdf

OECD (2006). Education at a Glance: Highlights 2006, Avaialble at https://www.oecd.org/education/skills-beyond-school/37376068.pdf 